GHANA JOURNAL OF DEPARTMENT OF HEALTH, PHYSICAL EDUCATION AND RECREATION, SPORTS AND DANCE (GJOHPERSD)

\author{
Volume 9, Year 2016
}

A JOURNAL OF THE DEPARTMENT OF HEALTH, PHYSICAL EDUCATION AND RECREATION (HPER)

UNIVERSITY OF CAPE COAST

GHANA, WEST AFRICA 


\title{
Knowledge of the Perceived Influence of Nutritional Supplements on Sexual Performance of Male Undergraduates in University of Ilorin, Nigeria
}

\author{
Oniyangi, Shuaib Olanrewaju \& Jamiu, AbdulQudus Tosin
}

Department of Health Promotion and Environmental Health Education, Faculty of Education, University of Ilorin. Ilorin, Nigeria.

ballackoluwatosin@gmail.com, +2347065348531

\begin{abstract}
This study investigated on Knowledge of the perceived influence of food supplements on sexual performance of male Undergraduates in University of Ilorin. Nutritional supplements are products intended to make up for a poor diet or to support our health in the same way that nutritious food will perform. This study investigated (i) influence of ginger as a nutritional supplement on sexual performance among male Undergraduates, University of Ilorin (ii) influence of watermelon as a nutritional supplement on sexual performance among male Undergraduates, University of Ilorin (iii) influence of banana as nutritional supplement on sexual performance among male Undergraduates, University of Ilorin. A descriptive research design of survey type was employed for this study. The population consists of all male undergraduates in University of Ilorin. A multistage sampling technique was used for the study. Simple random sampling technique was used to select four hundred and twenty seven (427) respondents for the study. Researcher's designed structured questionnaire which was validated by four experts from the Department of Health Promotion and Environmental Health Education; University of Ilorin was used for data collection. A correlation co-efficient of .82r was obtained through test retest method using Pearson Product Moment Correlation .Data collection was conducted by the researcher and four trained research assistants. The three postulated null hypotheses were tested using the inferential statistics of chi-square @0.05 alpha level. The findings from this study
\end{abstract}


Oniyangi, et al. reveal that; ginger as a nutritional supplement significantly influences sexual performance of male undergraduate with the calculated chi-square $\left(\chi^{2}\right)$ value of 311.010 is greater than the table chi-square $\left(\chi^{2}\right)$ value of 16.92 at the freedom (df) 9 @ 0.05 alpha level; Watermelon as a nutritional supplement significantly influences sexual performance of male undergraduate with the calculated chi-square $\left(\chi^{2}\right)$ value of 543.013 is greater than the table chi-square $\left(\chi^{2}\right)$ value of 21.03 at the freedom (df) $12 @ 0.05$ alpha level and Banana as a nutritional supplement significantly influences sexual performance of male undergraduate in University of Ilorin with the calculated chi-square $\left(\chi^{2}\right)$ value of 629.021 is greater than the table chi-square $\left(\chi^{2}\right)$ value of 25.00 at the freedom (df) 15 (a) 0.05 alpha level. Based on the findings of the study, it was concluded that ginger, watermelon and banana as a nutritional supplement influenced sexual performance among undergraduates, University of Ilorin. Therefore, it was recommended that male undergraduate students should be encouraged on the consumption of ginger which will serve a body building stimulant and increases the production of sperm motility, regular intake of watermelon which serves as hormone regulator and inhibitor to sexual performance should be taking more often among male undergraduate and knowledge of the consumption of banana intake as a treatment of intestinal disorders and erectile dysfunction should be intensified among male undergraduate students. 
Knowledge of the Perceived Influence of Nutritional Supplements on Sexual

Performance of Male Undergraduates in University of Ilorin, Nigeria

\section{Introduction}

Loss of sexual desire and function is a sign of physical illness and mental depression. Sexual arousal and intercourse are successful only when the nerves and blood vessels that service the sexual organs are healthy (Kunin, 2010). Marriage is the most important and most enjoyable of all human relationships. It is the true basis of all family life, and the importance of sex can never be underestimated in any marriage relationship, for this is the highest expression of physical love that human beings can enjoy. Many things can make a man not to be able to fulfill his sexual obligation to his partner (Bamidele, 2009). A man who is not able to perform sexually would experience emotional torment. Such an individual would not be regarded as a total man, especially of ours. Frigidity or sexual coldness in women is caused by lack of sufficient foreplay by men. Men tend to forget that women, by their nature are more slowly aroused sexually, and as a result they are often left unsatisfied and disappointed. However, men may be incapable sexually. This means that a man could also be defected sexually, and if care is not taken with the problem addressed on time, it may lead to impotence or other sexual defects such as sexual weakness, lack of exciting sexual drive, unsatisfactory sexual performance or weak erection (Bamidele, 2009).

Nutritional supplements are products intended to make up for a poor diet or to support our health in the same way that nutritious food will perform. Nutritional supplements are items that are usually considered non-food items that are used to enhance nutritional programme. Many supplements contain active ingredients that have strong biological effects in the body. They include a wide range of substances, including vitamins, minerals, amino acids and enzymes; herbs and other botanicals; and products like probiotics, glucosamine and fish oils (Bailey, 2010). Food supplements are food products, even though they may look like and be used in the same way as medicinal products. Food supplements include products for the intake of vitamins, minerals, fibre and fatty acids and various herbal products. The ingredients used must not have medicinal effects and they must not have been approved for medicinal use. Food supplements are normally used 
Oniyangi, et al.

for one of their nutritional characteristics, for instance as sources of vitamins, minerals or fatty acids, in order to supplement the diet. They may also have a physiological effect, for instance on digestion, blood pressure or cholesterol level. The natural product business has categorized food supplements in the following way, they include, Vitamins and minerals, Products containing plants or plant extracts, Fibre and weight control products, Lecithin and fatty acid products, Algae products, Bee products, Sports nutrients and other food supplements (Food supplements guide, 2008).

Bananas are excellent for improving male sexual function and lasting longer in bed. They provide the energy and nutrients our body needs to perform better in the sack. Bananas contain Vitamin B and Potassium which both play very important roles in the body's ability to make sex hormones. When a man's body has what it needs to produce male sex hormones, he will have a lot chance of lasting longer in the bedroom. Bananas are referred to as natural remedy for weak penile erection. It is a libido enhancing natural therapy that has no dangerous effect on the body organs like the heart as that of Viagra (Bamidele, 2009).

Ginger contains manganese. This mineral, found throughout the body, is essential to neurological health. By helping to form and trigger the release of the sex hormone testosterone, manganese is vital to your sex drive and sperm production (Morakinyo, Adeniyi \& Arikawe, 2008). Ginger helps to increase the flow of blood around the body and to the genitals and the herb has the same vacillating properties as green tea to dilate the blood vessels so they are wider and be able to carry more blood. Ginger inhibits the build-up of cortisol which can cause weak erections or erectile dysfunction and works to maintain healthy blood pressure and reduces cholesterol which if both are high, can reduce the flow of blood into the penis. Finally, the herb acts as an overall heart and circulatory and immune system tonic. Ginger, a known aphrodisiac, has been used for many years in arousing desire and enhancing sexual activity. Ginger's scent has its unique allure that helps in establishing the connection. Not to mention, ginger also help the blood circulation, hence blood flows more easily to the mid-section of the body (Ogungbemi, 2006). 
Knowledge of the Perceived Influence of Nutritional Supplements on Sexual Performance of Male Undergraduates in University of Ilorin, Nigeria

Watermelons have naturally occurring nutrients that can produce healthy reactions in the body. One of those nutrients is citeulline, which is converted to arginine through reactions initiated by enzymes. Arginine is a compound known to improve blood circulation throughout the entire body. Arginie boosts nitric oxide, which relaxes blood vessels, the same basic effect that Viagra has, to treat erectile dysfunction and even prevent it. Watermelon is used in the treatment of hypertension, prostrate cancer and heart diseases. Erectile dysfunction can be caused by stroke, hypertension, atherosclerosis, stress, radiation therapy to the testicles, multiple sclerosis etc. Not only does watermelon make a healthy summertime snack, it also has some nice sexual health benefits. Some who eat watermelon may achieve enhanced sexual intercourse within a short time after eating. The reason this fruit can help last in the bedroom by supplying nutrients that cause your body to increase blood flow down there (Pete, 2008).

Booth, Nowson, Worsley, Margerison \& Jorna (2008) added that despite males having a shorter life expectancy and being more susceptible to the medical consequences of chronic disease compared to their female counterparts, participation in preventive health services are lower amongst males. "Healthy eating" messages are presented by a range of media sources, especially internet based media, which can provide contradictory nutritional messages to readers or messages based on evidence with unknown scientific quality. For males, who most often do not seek professional consultation, this can lead to self-monitoring of their current health status based on instinctive assumptions from questionable evidence or utilizing uninformed partners and friends as a source of advice regarding diet and lifestyle behavior changes (Booth et al, 2008). There is relationship between food and sexuality in various ways throughout history. Foods such as chocolate, oysters are said to be aphrodisiacs. In some cultures, human testicles and other items are also consumed to increase sexual potency. (O'connor \& Anahad, 2006). Rosati (2015) affirmed that eating a healthy variety diet of nutritious foods rich with vitamins, minerals, antioxidants and pythonutrients such as 
carotenoids help us resist disease. The carotenoids found in most fruits and vegetables give our skin a healthy glow.

\section{Statement of the problem}

It was observed that many students do not have knowledge of specific nutritional supplements or some certain nutrients which enhances sexual performance. It was also observed that some students do not know the danger in taking certain diets as it affects their sexual performances. In addition, adequate attention is yet to be given on the need to educate the society at large on diets and its contribution to a healthy sexual life. Several studies have shown that the number of couples unable to achieve pregnancy is on the rise. Indeed, more men are firing blanks as a result of low sperm count and quality. Sometimes, the causes of low sperm count are infections. The infections, according to experts, affect the quality of semen by damaging the gonads. But there are many natural herbal and nutritional aphrodisiacs that enhance sexual drive and pleasure in both men and women, increase libido, improve sexual performance, blood flow, boost fertility, increase force and intensity of ejaculation (Hum, 2010).

Sexual health issues are not often linked to general health conditions that are caused by poor nutrition and lack of activity. Rarely will nutrition be examined, which is a problem, as it is a major factor in most illnesses. Many physicians simply provide prescription medications to address symptoms rather than helping the patient to explore helpful education that may promote natural, nutritional and sexual changes that address the core issue. After all, when one's diet affects things such as hormone levels, energy levels, mental health and physical and sexual performance, one must question why this is not the first area that is explored in addressing these issues as related to diet instead of a prescription drug (Lawless, 2013). The majority of sexual health problems can be attributed to bad nutrition. With diseases that contribute to sexual dysfunction, such as diabetes, high blood pressure, depression, poor blood flow, heart and thyroid conditions are all to lower the sexual performance level in the body. In addition, many people themselves have become unmotivated to make changes to 
Knowledge of the Perceived Influence of Nutritional Supplements on Sexual

Performance of Male Undergraduates in University of Ilorin, Nigeria

their diet. It is imperative for one to understand that not taking care of one's nutritional needs may not just cause general health and sexual health problems temporarily but also cause permanent damage and chronic disease. A little effort everyday can make the difference between a long, healthy and sexual fulfilling life and a life that is riddled with health problems including the inability to have sex (Lawless, 2013).According to Taboola (2015), many men suffer from a low sex drive, sexual performance problems, and an overall lack of male virility. These problems can negatively impact a man's self-esteem, sense of self-worth, and the quality of his romantic relationships. However, problems with male virility and sexual functioning can be, in most cases, be remedied through dietary factors that promote strong male virility and improve sexual function and performance.

Due to the large number of undergraduates that are yet to get married and those that are married, there is need for them to be educated on the importance of some certain healthy foods that may enhance their sexual performance. Therefore, in line with above statements and other scholarly reports, the researcher investigates the knowledge of the perceived influence of nutritional supplements on sexual performance of male Undergraduates, University of Ilorin.

\section{Research questions}

\section{The following research questions were raised to guide the study}

1. Will knowledge of ginger as a nutritional supplement be perceived as influencing sexual performance of Male Undergraduates in University of Ilorin?

2. Will knowledge of watermelon as a nutritional supplement be perceived as influencing sexual performance of Male Undergraduates in University of Ilorin?

3. Will knowledge of banana as a nutritional supplement be perceived as influencing sexual performance of Male Undergraduates in University of Ilorin? 


\section{Research Hypotheses}

\section{The following research questions were formulated to guide the study}

1. Knowledge of ginger as a nutritional supplement will not be perceived as influencing sexual performance by Male Undergraduates in University of Ilorin.

2. Knowledge of watermelon as a nutritional supplement will not be perceived as influencing sexual performance by Male Undergraduates in University of Ilorin.

3. Knowledge of banana as a nutritional supplement will not be perceived as influencing sexual performance by Male Undergraduates in University of Ilorin.

\section{Methodology}

Descriptive research design of the survey method was used for the study. The population consists of University of Ilorin students which comprised students from the fifteen (15) Faculties with a total number of thirty-six thousand four hundred and thirty five $(36,435)$ undergraduates as at the time of this study. The target population is all 300 level and 400 level male undergraduates in all faculties for $2015 / 2016$ session and their total population is seven thousand eight hundred and sixty nine $(7,869)$ from five selected Faculties in the University of Ilorin, Ilorin. A multistage sampling procedure of simple random sampling technique and proportionate sampling technique of ten percent $(10 \%)$ was used for the study. Simple random sampling technique was used to select five (5) faculties from the fifteen (15) faculties in the University. Based on the nature and resources needed to carry out the study, the researcher selected five (5) out of fifteen (15) available faculties using simple balloting technique, to select the faculties, the researcher wrote all the faculties name on a different sheet of paper, folded and placed in a container, someone picked five (5) needed faculties that was used for the study out of the fifteen (15) faculties named in the container. The first five picked faculties were used for the study. Purposive sampling technique was used to select $300 \& 400$ level based on their experiences and years spent 
Knowledge of the Perceived Influence of Nutritional Supplements on Sexual

Performance of Male Undergraduates in University of Ilorin, Nigeria

in the university. Proportionate sampling technique was used to select ten percent (10\%) samples from the five (5) faculties' selected based on population. Simple random sampling technique was used to select the actual respondents for the study.

\section{Table 1}

\begin{tabular}{|c|c|c|c|c|}
\hline & Faculties & $\begin{array}{l}\text { Population of } \\
\text { male } \\
\text { Undergraduate } \\
\text { students ( } 300 \& \& \\
400 \text { level) }\end{array}$ & $\begin{array}{l}\text { Sample } \\
\text { Percentage } \\
(10 \%)\end{array}$ & $\begin{array}{l}\text { Total } \\
\text { Sample }\end{array}$ \\
\hline 1 & Agriculture & 369 & 36.9 & 37 \\
\hline 2 & Arts & 557 & 55.7 & 56 \\
\hline 3 & $\begin{array}{l}\text { Communication } \\
\& \text { Information } \\
\text { Sciences }\end{array}$ & 412 & 41.2 & 41 \\
\hline 4 & Education & 1553 & 155.3 & 155 \\
\hline 5 & $\begin{array}{l}\text { Physical } \\
\text { Sciences }\end{array}$ & 1383 & 138.3 & 138 \\
\hline Total & 5 & 4274 & 427.4 & 427 \\
\hline
\end{tabular}

$10 \%$ of each faculty will be samples for this study.

A researchers' developed four likert rating scale questionnaire was used in data collection for the study. The questionnaire consists of two sections namely: section $\mathrm{A}$ and $\mathrm{B}$. Section A elicits information on the demographic variables of the respondents, while Section $\mathrm{B}$ elicits information on the variables under study. To ascertain the validity of this instrument, the researcher gave three copies to three experts in the Department of Health Promotion and Environmental Health Education, University of Ilorin. Their comments and suggestions in line with recommendations of the supervisor were carefully studied and used to improve the quality of the instrument. To determine the reliability of this instrument, the researcher adopt a test re-test method, questionnaire was administered to twenty (20) respondents from another Faculty from Kwara State University, Malete outside the area of study. Two weeks were allowed 
Oniyangi, et al. between the first and second administration. Both results were compared using Pearson Product Moment Correlation statistical analysis. A reliability coefficient ' $r$ ' of 0.82 was obtained and this was considered high enough for the study. In order for the researcher to gain the recognition from the respondents, a letter of introduction that was duly signed by the Head of Department of Health Promotion and Environmental Health Education, University of Ilorin. This letter was used for the purpose of instrument administration. The researcher made every effort with other three trained research assistants in administering the instruments and protected the confidentiality of the research participants. The data for this study was collected, sorted, coded and subjected to appropriate statistical analysis. Section A contains the demographic data of the respondents, was analyzed using descriptive statistics of frequency counts and simple percentage and non-parametric of inferential statistics of chi-square was used to analyze the stated hypotheses at 0.05 alpha level of significance using Statistical Package for Social Science (SPSS) version 20.0.

\section{Test of Hypotheses}

Hypotheses 1: Ginger as a nutritional supplement will not be perceived as influencing sexual performance of male undergraduates in University of Ilorin.

Table 1: Chi-square analysis of Ginger as a nutritional supplement will not significantly influence sexual performance of male undergraduates in University of Ilorin. 
Knowledge of the Perceived Influence of Nutritional Supplements on Sexual

Performance of Male Undergraduates in University of Ilorin, Nigeria

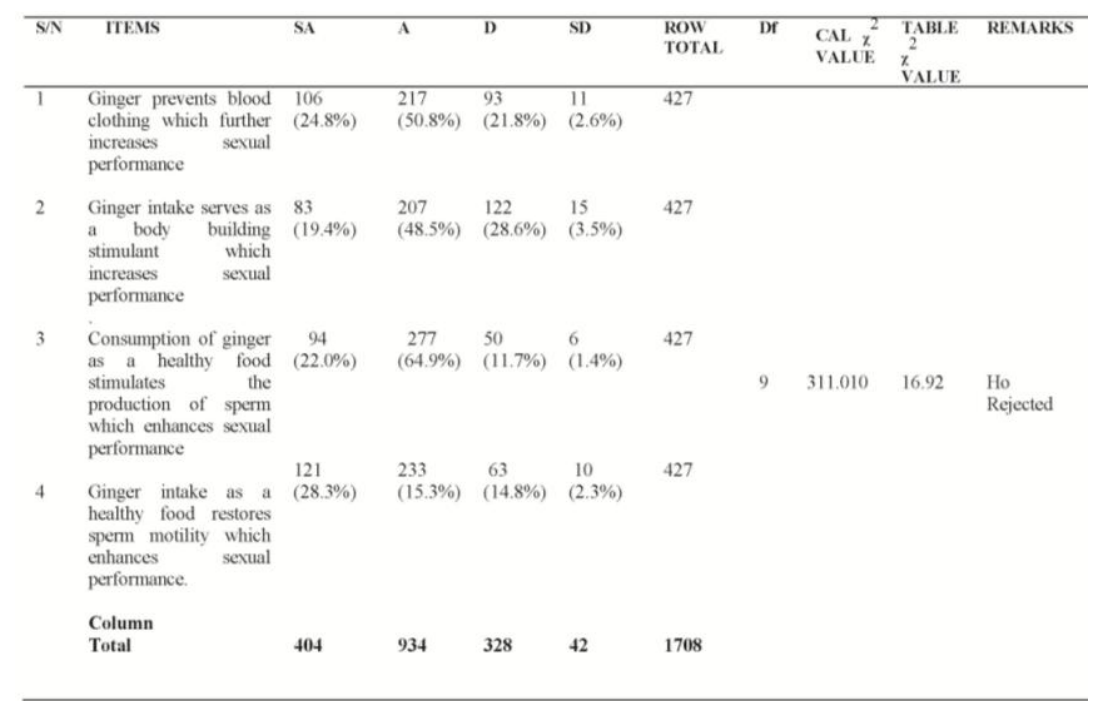

(a)0.05 alpha level

Table 1 revealed that the calculated chi-square value is 311.010 and the table ${ }_{\chi}^{2}$ value is 16.92 with the degree of freedom $9 @ 0.05$ alpha level. Since the calculated $\chi^{2}$ value of 311.010 is greater than the table $\chi^{2}$ value of 16.92 at 9 degree of freedom. Therefore, null hypothesis is rejected. This implies that Ginger as a nutritional supplement has significant influence sexual performance of male undergraduates in University of Ilorin. This implies that ginger stimulate the production of saliva and sperm in male which enhances sexual performance among male undergraduates in University of Ilorin.

\section{Hypotheses 2: Watermelon as a nutritional supplement will not be perceived as influencing sexual performance of male undergraduates in University of Ilorin.}

Table 2: Chi-square analysis of watermelon as a nutritional supplement will not significantly influence sexual performance of male undergraduates in University of Ilorin. 
Oniyangi, et al.

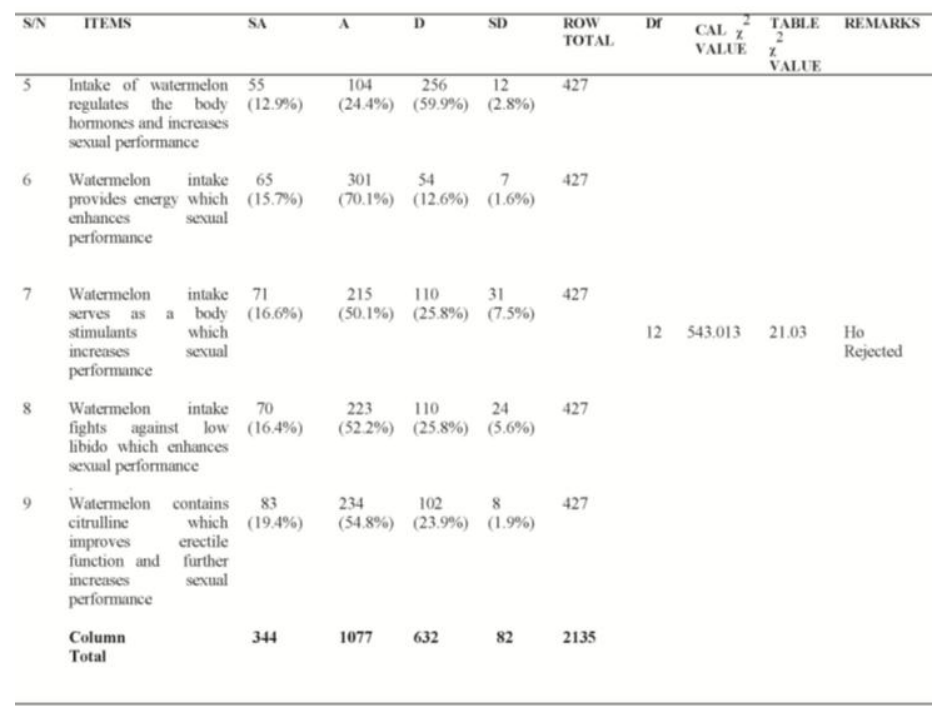

@0.05 alpha level

Table 2 revealed that the calculated chi-square value is 543.013 and the table $\chi^{2}$ value is 21.03 with the degree of freedom $12 @ 0.05$ alpha level. Since the calculated $\chi^{2}$ value of 543.013 is greater than the table $\chi^{2}$ value of 21.03 at 12 degree of freedom. Therefore, null hypothesis is rejected. This implies that watermelon as a nutritional supplement has significant influence sexual performance of male undergraduates in University of Ilorin. This implies that intake of watermelon regulates the body hormones and increases sexual performance among male undergraduate in University of Ilorin.

\section{Hypotheses 3: Banana as a nutritional supplement will not be perceived as influencing sexual performance of male undergraduates in University of Ilorin.}

Table 3: Chi-square analysis of banana as a nutritional supplement will not significantly influence sexual performance of male undergraduates in University of Ilorin. 
Knowledge of the Perceived Influence of Nutritional Supplements on Sexual Performance of Male Undergraduates in University of Ilorin, Nigeria

\begin{tabular}{|c|c|c|c|c|c|c|c|c|c|c|}
\hline $\mathrm{S} / \mathrm{N}$ & ITEMS & SA & A & D & SD & $\begin{array}{l}\text { ROW } \\
\text { TOTAL }\end{array}$ & Df & $\begin{array}{l}\text { CAL } x^{2} \\
\text { VALUE }\end{array}$ & $\begin{array}{l}\text { TABLE } \\
\chi^{2} \\
\text { VALUE }\end{array}$ & REMARKS \\
\hline 10 & $\begin{array}{l}\text { Banana intake } \\
\text { contains vitamin B } \\
\text { which increases } \\
\text { energy and boost } \\
\text { sexual performance }\end{array}$ & $\begin{array}{c}81 \\
(18.9 \%)\end{array}$ & $\begin{array}{c}207 \\
(48.5 \%)\end{array}$ & $\begin{array}{l}134 \\
(31.4 \%)\end{array}$ & $\begin{array}{c}5 \\
(1.2 \%)\end{array}$ & 427 & & & & \\
\hline 11 & $\begin{array}{l}\text { Intake of banana as a } \\
\text { food increases libido } \\
\text { level with the aid of } \\
\text { an enzyme called } \\
\text { bromelain which } \\
\text { increases sexual } \\
\text { performance }\end{array}$ & $\begin{array}{l}102 \\
(23.9 \%)\end{array}$ & $\begin{array}{l}203 \\
(47.5 \%)\end{array}$ & $\begin{array}{c}110 \\
(25.8 \%)\end{array}$ & $\begin{array}{l}12 \\
(2.8 \%)\end{array}$ & 427 & & & & \\
\hline 12 & $\begin{array}{l}\text { Banana contain } \\
\text { potassium used in } \\
\text { producing } \\
\text { hormones and sex } \\
\text { drive whe } \\
\text { improves sexual } \\
\text { performance in }\end{array}$ & $\begin{array}{l}92 \\
(21.5 \%)\end{array}$ & $\begin{array}{l}126 \\
(29.5 \%)\end{array}$ & $\begin{array}{l}184 \\
(43.1 \%)\end{array}$ & $\begin{array}{l}25 \\
(5.9 \%)\end{array}$ & 427 & 15 & 629.021 & 25.00 & $\begin{array}{l}\text { Ho } \\
\text { Rejected }\end{array}$ \\
\hline 13 & $\begin{array}{l}\text { Regular intake of } \\
\text { banana as a food } \\
\text { helps to improve the } \\
\text { blood flow that aids } \\
\text { sexual performance }\end{array}$ & $\begin{array}{l}75 \\
(17.6 \%)\end{array}$ & $\begin{array}{l}162 \\
(37.9 \%)\end{array}$ & $\begin{array}{l}176 \\
(41.2 \%)\end{array}$ & $\begin{array}{l}14 \\
(3.3 \%)\end{array}$ & 427 & & & & \\
\hline 14 & $\begin{array}{l}\text { Banana is a rich } \\
\text { source of vitamin A } \\
\text { which stimulate the } \\
\text { production and } \\
\text { improve sexual } \\
\text { performance }\end{array}$ & $\begin{array}{l}51 \\
(11.9 \%)\end{array}$ & $\begin{array}{l}71 \\
(1.8 \%)\end{array}$ & $\begin{array}{l}273 \\
(63.9 \%)\end{array}$ & $\begin{array}{l}32 \\
(7.5 \%)\end{array}$ & 427 & & & & \\
\hline 15 & $\begin{array}{l}\text { Banana intake } \\
\text { reduces the problem } \\
\text { of } \\
\begin{array}{lr}\text { dysfunction } \\
\text { boost }\end{array} \\
\begin{array}{l}\text { performance } \\
\text { sexual }\end{array} \\
\end{array}$ & $\begin{array}{c}114 \\
(26.7 \%)\end{array}$ & $\begin{array}{l}117 \\
(27.4 \%)\end{array}$ & $\begin{array}{l}174 \\
(40.7 \%)\end{array}$ & $\begin{array}{l}22 \\
(5.2 \%)\end{array}$ & 427 & & & & \\
\hline & $\begin{array}{l}\text { Column } \\
\text { Total }\end{array}$ & 515 & 886 & 1051 & 110 & 2562 & & & & \\
\hline
\end{tabular}

\section{@0.05 alpha level}

Table 3 revealed that the calculated chi-square value is 629.021 and the table ${ }_{\alpha}^{2}$ value is 25.00 with the degree of freedom 15 @ 0.05 alpha level. Since the calculated $\chi^{2}$ value of 629.021 is greater than the table $\chi^{2}$ value of 25.00 at 15 degree of freedom. Therefore null hypothesis is rejected. This implies that banana as a healthy food has significant influence on sexual performance of male undergraduates in University of Ilorin. The implication of this is that banana intake reduces the problem of erectile dysfunction which boosts sexual performance of male undergraduate students in University of Ilorin. 


\section{Discussion of findings}

Hypotheses I: -Stated that knowledge of ginger as a nutritional supplement will not be perceived as influencing sexual performance by Male Undergraduates in University of Ilorin. The analysis of the calculated chi-square calculated $\chi^{2}$ value of 311.010 is greater than the table $\chi^{2}$ value of 16.92 at 9 degree of freedom. Therefore, null hypothesis is rejected. This implies that Ginger as a nutritional supplement has significant influence on sexual performance of male undergraduates in University of Ilorin. This finding is in line with Ogungbemi (2006) who affirmed that ginger helps to increase the flow of blood around the body and to the genitals and the herb has the same vacillating properties as green tea to dilate the blood vessels so they are wider and be able to carry more blood. This finding was further supported with Amir, Eldin and Hamza (2007) who opined that ginger displays antiinflammatory properties and can be used to treat rheumatoid arthritis, osteoarthritis, and various other muscular disorders and production of saliva and sperm needed in enhancing sexual performance.

Hypotheses II: -Stated that knowledge of watermelon as a nutritional supplement will not be perceived as influencing sexual performance by Male Undergraduates in University of Ilorin. The analysis of the calculated chi-square calculated $\chi^{2}$ value of 543.013 is greater than the table $\chi^{2}$ value of 21.03 at 12 degree of freedom. Therefore, null hypothesis is rejected. This implies that watermelon as a nutritional supplement has significant influence on sexual performance of male undergraduates in University of Ilorin. This finding is in line with Carrieri, Cormio and Lorusso (2011) who explained that watermelon is a natural alternative treatment for mild and moderate erectile dysfunction in men who fear the drug's effects on the body and it contains citrulline which helps in excretory pathway further increases sexual performance.

Hypotheses III: -Stated that knowledge of banana as a nutritional supplement will not be perceived as influencing sexual performance by Male Undergraduates in University of Ilorin. The analysis of the calculated chi-square calculated $\chi^{2}$ value of 629.021 is greater than the table ${ }_{\chi}^{2}$ value of 25.00 at 15 degree of freedom. 
Knowledge of the Perceived Influence of Nutritional Supplements on Sexual

Performance of Male Undergraduates in University of Ilorin, Nigeria

Therefore, null hypothesis is rejected. This implies that banana as a nutritional supplement has significant influence on sexual performance of male undergraduates in University of Ilorin. This finding is in line with Bamidele (2009) who affirmed that bananas are natural remedy for weak penile erection. It is a libido enhancing natural therapy that has no dangerous effect on the body organs like the heart as that of Viagra. Bamidele (2009) also explained that bananas are high in bromelain and $b$ vitamins, both of which are potent sexual hormone regulators that can help improve sexual function, sexual desire and sexual virility and boost sexual performance.

\section{Conclusion}

Based on the findings of the study, the following conclusions were made:

1.) Ginger as a nutritional supplement influenced sexual performance of male Undergraduates in University of Ilorin.

2.) Watermelon as a nutritional supplement influenced sexual performance of male Undergraduates in University of Ilorin.

3.) Banana as a nutritional supplement influenced sexual performance of male Undergraduates in University of Ilorin.

4.)

\section{Recommendation}

Based on the conclusion of the study, the following recommendations were made:

1. Male undergraduate students should be encouraged on the consumption of ginger which will serve a body building stimulant and increases the production of sperm motility.

2. Regular intake of watermelon which serves as hormone regulator and inhibitor to sexual performance should be taking more often among male undergraduate.

3. Knowledge of the consumption of banana intake as a treatment of intestinal disorders and erectile dysfunction should be intensified among male undergraduate students 


\section{References}

Amir, A., Alaa Eldin, A. \& Hamzaa, A. A. (2007). Effects of ginger and Roselle on Cisplatin induced reproductive toxicity in rats. Asian Journal of Andrology. 5; 607 - 612.

Bailey, R. L., Dodd, K. W., Goldman, J. A., Gahche, J. J. (2010). Estimation of total usual calcium and vitamin D intakes in the United States. Journal of Nutrition, 140(4), 817-822.

Bamidele, O. (2009). Health affairs. Unripe plaintains: Boosts sex drive, prevent ejaculation.

Booth, A., Nowson, C., Worsley, A., Margerison, C., Jorna, M. (2008). Dietary approaches for weight loss with increased intakes of fruit, vegetables and dairy products. Nutritional Diet. 65, 115-120.

Carrier, G., Cormio, L. \& Lorusso, F. (2011).Supplementation improper erection hardness in men with mild erectile dysfunction. Italy.

Food Supplement Guide (2008).Food supplement. Available from http://www.palvelu.fi/evi/files/55 519 470.pdf, Retrieved on $23^{\text {rd }}$ May, 2015.

Hum, M. (2010). DHD nutritional therapist and health journalist. Institute for optimum nutrition. Nutritional diet. 65,115 120.

Kunin, A.D. (2010). Sex and nutrition. Available at http://www.olaloa.com/sex-andnutrition.html , Retrieved on 6th October, 2015.

Lawless, S. L. (2013).The importance of nutrition and sexual health.

Available

at

http://www.naturalnews.com/042792 nutrition intake sexu

al health holistic medicine.html, Retrieved on 6th November, 2015.

Morakinyo, A. O, Adeniyi O. S, \& Arikawe, A. P (2008). Effects of Zingiber official on the reproductive functions of Male. African Journal of Biomedical Research. 11:329 - 334.

O'Connor, A. D. \& Anahad, S. G. (2006). The claim: Chocolate is an aphrodisiac. The New York Times. Retrieved on 6th October, 2015. 
Knowledge of the Perceived Influence of Nutritional Supplements on Sexual

Performance of Male Undergraduates in University of Ilorin, Nigeria

Ogungbemi, T. (2006). Outlines and pictures of medicinal plants in Nigeria. $\left(1^{\text {st }}\right.$ ed). Lagos, Spectrum Books

Pete, P. (2008). Baby seedless watermelon. Seedless watermelon. Available at http://www.producepete.com/index.html, Retrieved on $14^{\text {th }}$ November, 2015.

Research Advisor (2006).Sample size table for researcher. Available from http://research- advisors.com, Retrieved on $16^{\text {th }}$ January, 2016.

Rosati, L .M. (2015).Sex and Health. Available at http://www.sharecare.com/health/sex-and-

relationships/good-diet-important-for-sex. Retrieved on 6th October, 2015.

Taboola, F. (2015). Vkool today. Foods for sex. Available at http://vkool.com/foods-for-sex/ Retrieved on 6th October, 2015. 